\title{
Paideusis
}

\section{Over-standing and Under-standing: Reason and Education in the Thinking of George Grant}

James G. Calder

Volume 5, Number 1, 1991

URI: https://id.erudit.org/iderudit/1073353ar

DOI: https://doi.org/10.7202/1073353ar

See table of contents

Publisher(s)

Canadian Philosophy of Education Society

ISSN

0838-4517 (print)

1916-0348 (digital)

Explore this journal

Cite this article

Calder, J. (1991). Over-standing and Under-standing: Reason and Education in the Thinking of George Grant. Paideusis, 5(1), 3-19.

https://doi.org/10.7202/1073353ar 


\title{
Over-standing and Under-standing: Reason and Education in the Thinking of George Grant
}

\author{
James G. Calder, St. Peter's, Nova Scotia
}

\begin{abstract}
Modern academic writing is strewn with impertinent precis written by those who think they can say in fewer words what wiser men than they have said in more. ${ }^{1}$
\end{abstract}

Let this quotation stand as a legend over this essay into the writings of George Grant. In what follows, no attempt will be made to precis the whole of the thinking about this subject that his words trace upon the printed page. Like the beauties of sound in a Mozart concerto, that thinking reaches far beyond the grasp of my comprehension. To understand philosophers of Grant's depth and beauty means, literally, to stand under the grandeur of their thinking. In such writings, of course, it is just what reaches beyond us that draw us back to them. Their beauty is compelling.

What will be attempted here is a precis of a more restricted and of a less than definitive nature. The attempt will be to trace the content of something of central importance in Grant's writings, namely, the character of reason and its relation to the best education for the human being.

The first section will trace Grant's account of reason as it is given to us within the technological present of our society. In part two, this account will be contrasted with his delineation of reason as philosophic. In the third and final section, his thinking about education will be situated within the context of his thinking about reason as technological and as philosophical.

We do not find in Grant's writings a "philosophy of education" in the current sense of an attempt to formulate a consistent account of the meaning of the word. For Grant, as the title of one of his most brilliant essays indicates, the path of philosophy is not of but about. His thought is not of education; he is thinking about education, and what lies about it and the realities of reason within the technological and philosophical stances of our being.

\section{I}

One of the most frequent analogies Grant employs to represent our experience as technological beings is that of the "tightening circle"."

The tight circle in which we live is this: our present forms of existence have sapped the ability to think about standards of excellence and yet at the same time have imposed on us a standard in terms of which the human good is monolithically asserted. ${ }^{3}$

What his thinking encounters at the heart of this experience, at the epicentre of this ever tightening circle, is the paradigm of knowledge that is modern science.

Every civilization has its own paradigm of knowledge; its own account of what and how it is to know. Such paradigms lie at the core of civilizations, rendering them distinct from each other. Naturally, by defining such a basic stance of the human being towards being, such paradigms function to colour and shape all aspects of a society and the ways characteristic of being human within it.

Grant is very clear in his definition of what is essential in the character of such paradigms. Repeatedly, he tells us that they consist in the relation between 
an aspiration of human thought and the effective conditions for its validation. 4

In the modern scientific paradigm, that is ours in the heart of technology, the aspiration of thought is to power in the form of mastery and dominion over being (human and non-human alike). The effective condition for the realization of that aspiration is the stance of 'scientific objectivity' enfolded toward making.

In his later writings, his thinking about the character of this stance of the human being to being--'objectivity'--becomes clearer.

What is given in the modern paradigm is the project of reason to gain objective knowledge. What is meant by objective? Object means literally something that we have thrown over against ourselves. Jacio I throw, $o b$ over against; therefore 'the thrown against'. The German word for object is Gegenstand--that which stands against. Reason as project, [that is, reason as thrown forth] is the summoning of something before us and the putting of questions to it, so that it is forced to give its reasons for being the way it is as an object. Our paradigm is that we have knowledge when we represent anything to ourselves as object, and question it, so that it will give us its reasons.

This activity of summoning and questioning calls for carefully defined procedures. In the English-speaking world we call these methods 'experiment' and 'research'.

To look at being 'objectively' is for a subject to stand toward being in a certain way. Such a subject stands over being. In this over-standing of being what is known is always something smaller, something lesser than the known and the knower. From its inception it was recognized that the truths of the new, objective sciences were small truths; small truths, however, that were accessible to our intelligence and which could be held with a newfound certainty. They were also small truths that quickly accumulated into something important: power over the 'objective' or 'physical' realm of being which surrounds us and in which we ourselves exist.

Grant insists that the "novelty" of "technology' lies in the intrinsic folding of objective knowing toward making. It was not simply a novel way of knowing the world that was born with the new sciences of the sixteenth and seventeenth centuries. What then came forth was 'technology': a way of knowing intrinsically folded toward changing or re-making the world. It is precisely, in his view, this enfolding of objective knowledge toward making that distinguishes the technological stance of our civilization from all others, past and present. As a neologism coined by the Americans, the very word--'technology' --captures the novelty of its advent.

It is important to be clear about Grant's description of the stance of objectivity. For the objective knower, being is summoned forth into his or her presence as a subject. However, in the stance of being that is objective, it is not only the being summoned forward but also the knowing to subject who is deliberately reduced or diminished in their being. In order to know another being as objective, such knowers must voluntarily renounce their own subject-ivity. Such a knower must, for example, renounce the natural response of a human subject to beauty which is love. In various and profound ways, love can interfere with and inhibit the acquisition of objective knowledge about other beings. 
This aspect of the stance of objectivity has often been brilliantly described in modem literature. There are few better descriptions than that provided by John Fowles' stunning first novel, The Collector. It is perhaps best to stop here momentarily and listen, by way of illustration, to the words of Ferdinand Clegg, the central character of this novel and the "collector" of its title.

He is a man who likes, as he puts it, 'to do things scientific'. He begins by collecting butterflies and ends by collecting women in a dungeon beneath his basement. The novel provides us with a chillingly lucid portrait of an extreme 6 in the psychological disjunction of knowing and loving that stands, in Grant's description, at the heart of our being within technology.

Of course, she made me feel all clumsy and awkward. I had the same feeling I did when I had watched an imago emerge, and then you have to kill it. I mean, the beauty confuses you, you don't know what you want to do any more, what you should do. ${ }^{7}$

For the voice behind these words, knowing is merely a matter of collection and classification but as such it is still enfolded toward action. The butterfly cannot be either collected or classified until it is killed. (For living beings the rigour of classification demands the rigour of mortis.) Little can be learned objectively of other beings, if we simply let them be. What can we know of the butterfly as an object unless we kill it with a view to dissection, hold it with a view to vivisection or otherwise experimentally put the physicality of its being to the question?

Clegg is lucid in his description of the conflict that arises within our feelings when being appears to us as beautiful in the midst of the project of objective reason. Beauty confuses, confounds and--at least momentarily--inhibits the simple intention of that project.

To love, Grant maintains, is above all to be compelled to consent to the otherness of being. The lover is not willing to kill or otherwise transform the beloved with a view to knowing the truth about the beloved as an object! If the world is to be known objectively, love must be held in check and beauty banished.

The banishment of beauty is a key element in Grant's description of the objective stance of our knowing as technological beings. When we stand toward being as objective subjects, other beings appear to us on a level and from a perspective that excludes beauty and the response it automatically calls forth from us: love. To focus attention on the objective aspect of being is to focus on something from which beauty is absent. Even the most beautiful of beings can be studied and known objectively. The butterfly and the Mozart concerto can both be studied as objects without the beauty of either ever appearing to the knower who stands objectively outside his or her own 'subjectivity'.

In Grant's view, this aspect of the new science was intensified by the historical circumstances surrounding its inception. This consciously reductive aspect of modern science--explicit in the stance of objective knowing--was first formulated in terms of a critique of the teleological account of being given in Aristotle (at its height) and in medieval and later Christian theology (at its decadence). He reminds us that Dante, appropriately, placed St. Thomas Aquinas amongst the moderns.

Of course, to describe being objectively is to describe it without purpose as well as without beauty. 
For the human being, beauty endows being with intrinsic purpose. The purpose of being perceived as beautiful is to be. When the butterfly or the concerto appears before us as beautiful, we experience a purpose that goes beyond both the being perceived and the being perceiving. Beauty calls forth our consent to being (love). In the presence of the beautiful, we are content to let being be, to allow, for example, a being that we know and name, 'butterfly', to emerge and unfold before us as the being it is.

For Grant, this is clearly seen in the extension of the paradigm of scientific knowing from 'nature'--from the objective knowing of that which we not produce--to 'history'--the realm of being that we do bring forth. As we shall see later, it shines forth for him with great clarity in what occurs when the beings whom we objectively summon before us as objects are the greatest works of human art.

Within the curriculum of modem education, the stance and methods of scientific objectivity have reduced the living artifacts of our culture to the dead level of the museum and the mausoleum. To stand over the Bible, the Vedanta, a play by Shakespeare, a Bach cantata or, in general, our doings, sayings and makings as a species, in the way of objectivity, is to stand toward these things in such a way that we can learn much about them as objects but nothing at all from them. It is to stand so as to be untouched by the beauty in such works. To stand, in Grant's estimation, so that their beauty cannot lead us to anything beyond themselves and us.

Supposedly, the objective stance is the modern method by which we apply scepticism and doubt to the realm of being. In Grant's description, however, the scepticism of modernity is strangely incomplete. The one thing which was originally and is increasingly exempt from the application of methodical doubt is the technological enterprise itself. As we come to know and interfere with the objective aspects of being in ever more basic and novel ways, the less we question the technological destiny that is our own. As the circle tightens, nooselike, around the stance of reason within technology, the more difficult it becomes for reason to under-stand our experience and destiny within the circle.

In conclusion, it should be stated that for Grant--as for anyone who is partially or occasionally sane amidst the present--there is no question of the efficacy of the modern scientific method. The simple fact that the method works is not at issue in his thinking.

Obviously, much has been and much can be learned through the reduction of being to the level of object. We are dazzled, and rightly, by the truly astonishing wealth of detail in what we have come to know about the physical necessities governing 'nature' and ourselves. It is not what is given in the project of reason known to us as 'technology' that is the ultimate focus of Grant's thinking. On the contrary, his focus is on precisely what is not given in that project. His attention is engaged by all that is left out and purposely excluded from attention within the ever tightening, the ever more empty, and the ever more claustrophobic circle.

"To describe a destiny," he reminds us, "is not to judge it." However, throughout his writings it is clear that the more lucid and complete the description, the easier and more unequivocal becomes the possibility of rational judgement in its highest form: philosophy. 
The great hope implicit in confining reason within the tightening circle of technology is that claustrophobia (unto extinction) will ultimately drive reason to break out of the circle. A fact, he writes,

begins to appear through the modemity which has denied it: human excellence cannot be appropriated by those who think of it as sustained simply in the human will, but only by those who have glimpsed that it is sustained by all that is. ${ }^{8}$

For those given such glimpses, for those who continue to affirm against the sway of modernity,

justice or injustice of some actions can be known in advance of the necessities of time and of the calculation of means, there is a pressing need to understand our technological destiny from principles more comprehensive than its own. This need lifts us up to ask about the great westem experiment in a more than piecemeal way. It pushes us to understand its meaning in terms of some openness to the whole which is not simply sustenance for the further realization of that experiment. ${ }^{9}$

This passage continues, however, with a dark warning for those unduly optimistic about the ease and, indeed, about the very possibility of the confrontation of reason with technology today.

The exigency of our need for understanding must not blind us to the tighten-

ing circle in which we find ourselves. We are called to understand technological civilization just when its very realization has radically put in question that there could be any such understanding.

Within the tightening circle of technology, all understanding is denied and excluded in favour of the standing of reason over being in the scientific project of objective knowing.

It is, he reminds us, well to remember that our task, the task of reason in openness to the whole, is to understand technology. We must stand under the greatness of being that is technology, just as we must stand under the greatness of any form of being that we wish to understand. The difficulty in this, especially at present, is that we live in a civilization in which knowing as the over-standing of being has come to the very apogee of its dominance.

Within the tightening circle, we can neither stand over nor under technology. Within the circle, technology does not and cannot appear as it is. The possibility of philosophy, for Grant, depends upon the possibility of reason breaking out from the tightening circle.

In Grant's characterization, philosophic reason adopts a particular stance toward being, just as reason does in the focus of modern scientific objectivity. At first glance, his description of the stance of philosophic reason appears deceptively simple: reason stands in "openness to the whole".

As we have seen, where the stance of scientific objectivity is over being, the stance of philosophic reason is under being. To be open to the wholeness of any particular being is to be open to that which towers indefinitely above our comprehension or understanding. For this stance of reason, the aspiration of thought is far more likely to be a knowing enfolded towards contemplation than it is toward the re-making and transforming of being. It is folded in this direction, Grant suggests, because at its heart there lies an authentic form of scep- 
ticism, in the shape of a constant and inescapable awareness that no matter how much we know about any given being, that knowledge is as nothing compared to the whole. Can we ever fully know any being even if we reduce that being to the level of object? Surely even in the simplest 'objects' there is always something that escapes our knowledge.

The stance of reason in modem science only exists and progresses with its accumulation of knowledge about objects by denying that openness to the whole described by Grant as the heart and soul of reason. In any time and place, the stance of reason, as philosophy, exists in opposition to society. Inevitably, philosophy challenges,

the fundamental presuppositions that the majority of human beings inherit in a civilization, and which are so taken for granted as the way things are that they are given an almost absolute status. ${ }^{10}$

In our time, however, the ancient opposition between philosophy and society reaches its apogee. At no time in the records of our past has philosophy faced a civilization founded and centred upon an account of reason that claims to transcend and presumes to stand over all other accounts of reason. In our technological civilization, the project of reason as scientific objectivity is taken as the project of reason, pure and simple. Like everything else, previous accounts of reason are subject to the overstanding of objective reason. As moderns, living within the paradigm of scientific rationality, we tower over our past, including that portion of the past that is, in Grant's view, the height to which western rationality has reached--the philosophic tradition pursued by Socrates and Plato.

The opposition between the 'natural philosophy' that was to become modern science and philosophy, as it has been and is traditionally understood in the West, could not be greater or more complex. Technology, the enfolding of that natural philosophy towards making, could only come to be and can only continue its enterprise by denying, restricting and, if possible, killing the traditional western philosophic account of reason. One of the most powerful ways in which it does so, of course, is to call western philosophy and its past forward as object. For instance, one such view holds that the objectivity of modern scientific reason is a superior development from the philosophic reason of antiquity. In its modern superiority, objective reason towers over what it interprets as its primitive and small beginnings in philosophy.

In a fashion that is somehow characteristically 'modern', what this view forgets is that the greatness of being lies in its beginning, in the origin-al moment of its appearance out of nothingness. The great enterprise starts great. The greatness of being is momentous for it lies in the fact that the whole of its unfolding is enfolded in the moment of its appearance. The greatness of the tree is never greater than in the seed from which it grows for the whole unfolding of being that belongs to the tree is present in the seed. The greatness of the human being is never greater than in the moment of conception, the original moment of appearance out of which our being will unfold.

The greatness of being is not the monumental greatness of history, it is not the end to which being comes for, in time, we are all beings toward death or dis-appearance. In the end of our journey in time, the greatness of our being fades and disappears. Even the 'monuments' of our civilization and graveyards 
fade into that oblivion in which we can find, apart from the lie of history, no greatness.

\section{As Heidegger reminds us:}

A small beginning belongs only to the small, whose dubious greatness is to diminish all things; small are the beginnings of decay, though it may later become great in the sense of the enormity of total annihilation."1

If the beginnings of technology--" "the great western experiment"--were, indeed, something small, then we have glimpsed an additional aspect of the dark anxiety that overshadows the path of Grant's thinking about technology.

What lies at the heart of technology as objective knowing denies what lies at the heart of the ancient western account of reason. What hope we have lies in the fact that the contrary is not true. The old account and language of reason does not deny the truth of the project of reason as objective knowing. Our hope is that, in and through that account and language, we can come to under-stand technology and the destiny that is our own within it.

The darkness of Grant's vision concerning the present-day task of philosophy is rooted in his wise uncertainty. Is the present darkness of reason within the tightening circle the darkness of twilight or dawn? Who knows? The certain but so far mistaken optimism of Hegel--to the effect that the owl of Minerva takes flight at dusk--echoes ironically throughout Grant's writings.

The problem of language is, for Grant, one of the first and greatest problems which philosophic reason faces in awakening to its imprisonment within the confines of the tightening circle of technology. The new paradigm of objective knowledge has only been formed by re-forming and to great extent destroying the traditional language in which western reason (at its height and in its decadence) found expression. Along with Aristotle's language of purpose, Plato's language of beauty, justice, and good had to be overcome and had to be kept in exclusion, if the modern paradigm of objective knowing was to gain the complete ascendancy required for the uninhibited free play of technology with being.

Within the ever more constricted circle of technology, reason finds language increasingly inadequate to the expression of that thinking which is open to the whole. Increasingly, Grant concludes, language functions within the circle as a kind of mirror.

... which throws back the very metaphysic of technology which we were supposed to be deliberating about in detail. ${ }^{12}$

In his on-going attempt to be taken by language beyond the limitations of the circle, Grant forces his thinking to confront the "novelness" of technology. In this, his attention focuses on the novelness, the strangeness, of the very idea of 'novelty' within technology.

In the progress of technology, we are perpetually being confronted with the "new" and the "novel". We have, in fact, come to think of originality in terms of the newest, the latest, the most recent and novel of our makings. Perhaps at no other point do we confront the genuine novelty, the authentic strangeness of what technology itself is, than in this: for us, the origin-al, that which is of the origin, is the newest and latest.

For instance, we have come to believe that the originality of the computer lies in the novelty of its appearance in our time. We pride ourselves on belong- 
ing to a civilization 'creative' and 'original' enough to have brought it forth. Clearly, however, the origins of the computer do not lie within our civilization. Whatever its chronological or 'historical' origin, it is buried in a past that lies far beyond the time of our civilization. The seed that makes its appearance to us possible--as something great or as something small--was surely present in the mathematical speculations of antiquity.

The problem of origins--which lies behind any concept of origin-ality, is overcome in modernity only by the over-standing of objective reason. Supposedly, the ultimate mystery in the problem of origins--that there is something rather than nothing -- solved by the fact that we are. The credo of modernity is not Descartes' 'I think (or at least doubt), therefore I am' but rather 'I am, therefore everything else is'.

By standing over the authentic mystery of being, objective reason makes the problem seem simple. We are the source of being. We are the origin of the beings who come forth into appearance through us in 'history'. The 'ideas' that allow us to manipulate 'nature' so as to bring them forth are the products of our minds. We are also the origin of the beings we perceive around us in 'nature' for they appear to us (or fail to appear to us) through the limits of the reach of our minds into 'nature'. The beings outside us are simply our 'interpretations' of 'matter in motion'.

Such a solution, of course, increases both the intensity and the magnitude of the original mystery. If it is deeply mysterious that we and other beings are, how much more mysterious is it that we find ourselves the supposed 'source' of being? In its sheer, impenetrable illogic such a position reaches far beyond the old mystery of religion (and philosophy). The origin of being is God. But, of course, in the objective stance, no mystery appears. There is no mystery in an 'object', an object is a being deprived of its mystery. When we stand objectively over the problem of originality, the mystery of being does not dis-appear it simply fails to appear to us by virtue of perspective. To stand toward being objectively, to stand over being, is to stand so that the mystery of being (in which the wonder of reason is rooted) does not appear. The objective stance banishes--at one and the same time--both the authentic mystery of being and the spurious mystery of our being gods or, at least "supermen", in nature.

For Grant, to be open to the whole is to stand under the mystery of being as it reaches indefinitely beyond us. The contemplation of the authentic mystery of being is the end to which reason in its philosophic (and religious) mode brings us. The task of philosophy on this path--its traditional path--is the dissipation of the spurious and unauthentic forms of mystery to which our civilizations give rise. The account of knowing as objective given in technology is the most powerful of all the rationally illegitimate forms of mystery to arise against philosophy in either the west or the east.

In the tightening circle of the technological present, the weight of our civilization is set against the raising of the question concerning being. Yet, technology itself is the assertion of a particular answer to the question. Time and again, Grant's thought penetrates to the core of this contradiction. In those moments, the old reason of philosophy in the West flashes forth as that which is still very much alive.

For many of us--whether it be dawn or dusk--the wings of Minerva's owl sound in the path that George Grant's thinking traces upon paper and impresses 
upon the minds of those of us who had the pleasure and good fortunate of hearing him.

To be open to the whole means to be open to that which is origin- al; to be open to the momentous greatness of the beginning. In his view and philosophical tradition, the wholeness of being is not to be found in the monumental end to which being comes in time and 'history'. On the contrary, the wholeness of being is present in the original moment of its bursting into appearance. Traditionally, the concern of western philosophy lay with first questions. In modern and pre-modern history of our philosophy, thinking aspired towards finding that which is 'basic' or 'fundamental', that which underlies as a 'ground' or stands behind as a 'source'. In effect, its search has always been for that which is origin-al or of the origin.

The seemingly 'backward' sweep of Grant's thought is to be understood in this context. Chronologically (or 'historically') speaking, his thinking pushes through modern philosophy back to Plato and Socrates, the height of the beginning moment of reason in the form of western philosophy. By attempting to understand the texts that have been preserved from this height, Grant is attempting to re-gain the ancient language of reason from which technology springs and from which it excludes us. Stubbornly, persistently, his thinking insists on raising questions that are first questions in the traditional sense of our philosophy.

In Grant's writings the path of his thinking is about technology. In this movement of his attention around what lies about the focus of technology--the paradigm of objective knowing enfolded toward making--his thought encounters much that is novel in the sense of strange and wonder provoking.

For instance, his thinking encounters the distinction between 'fact' and 'value' that has always stood, in varying forms, at the heart of the modern paradigm of objective knowing. In thinking what lies about technology, his thought encounters perplexing contradictions. Look, he says:

where the fact-value distinction was originally formulated by Weber as a means whereby the academy could hold itself free from the pressures of the powerful, it has quickly become in North America a means whereby the university can make itself socially useful ... the very idea that good and bad are subjective preferences removed one possible break from the triumphant chariot of technology. ${ }^{13}$

'Scepticism', in its modern form, is another of these strangely novel aspects of our experience that is encountered in the journey of his thinking around the centre of the tightening circle.

The mark of education is claimed to be scepticism about the highest human purposes, but in fact there is no scepticism in the public realm about what it is important to do. ${ }^{14}$

Such remarks go to the heart of our 'historical' fate as beings of and within technology. We are led to wonder how we have come to these things, and in this wonder our minds are thrown back away from the technological centre to what lies in the past and on the periphery--that which lies as origin-al behind the novelty of our current situation.

Again and again in his thinking about technology, Grant encounters a central contradiction. While the modern scientific paradigm has nearly emptied 
and nearly silenced the old western philosophic language of beauty, justice, and good, it has--at the same time--been enfolded toward making on scales and to an intensity hitherto unknown to humanity. We are subject to ridicule if we employ the ancient language of 'good' at the very moment when we are subject to the monolithic assertion of a largely unquestioned, and increasingly unquestionable, account of wherein the human good lies: technological empowerment with a view to mastering 'nature'. We are awakened here by a void at the heart of our experience to ask: how have we come to this?

Why is technology exempt from the scepticism in which we take such pride?

Why is the objective stance of knowing in modern science intrinsically enfolded toward making?

Against the constriction of the technological circle, such questions push our thinking backwards toward the origin-al or primal moments out of which the present has unfolded.

Is there some primal affirmation which is 'before' technology--that is before our sciences and techniques, before our political and social ways, before our philosophies and theologies? When the 'before' in that sentence is thought chronologically (or, as we like to say, historically), was there some originating affirmation made somewhere and sometime when Europeans defined themselves over against the classical civilization they were inheriting? ${ }^{15}$

In Grant's view, reason has not yet penetrated to such an account. At its heart and in its origin, technology remains untouched by philosophy in either the direction of denial or of affirmation. Reason has yet to give us the truth concerning technology. The modern affirmative account of technology--German 'historicism' at its height in the writings of Nietzsche and Heidegger--remains for him unconvincing. The account which attempts to under-stand technology, thereby giving us the truth that stands within it and saving us from the blindness of our destiny as a civilization, remains unthought (or, at least, either unread or unwritten). And the light in which it must be thought--at its brightest in the ancient language and tradition of the Greeks and, especially of Plato-is obscured for us by the very darkening being that it is today called forth to illuminate.

\section{III}

It ought to be obvious by this point that, for Grant, the stance befitting the human being as 'educated' is the philosophic stance of "openness to the whole". In his later writings, especially in the wonderful essay entitled "Faith and the Multiversity", the philosophic or rational content of the term "education' is laid out with brilliant clarity.

Perhaps we can put it this way: in his paradigm of philosophy, the aspiration of thought (in "openness to the whole") is the understanding of being. The effective condition for the realization of that understanding is faith (as opposed to the doubt that has become central with the paradigm of technology).

In this context, he quotes the beautiful and profound formula of the one contemporary thinker whose thinking was the least constrained by the tightening circle of the technological paradigm--Simone Weil. 
Faith is the experience that the intelligence is enlightened by love. ${ }^{16}$ And what is love?

[C]onsent to the fact that there is authentic otherness. ${ }^{17}$

For Grant, as for Simone Weil--and for Plato and Socrates before them--to think is, above all to pay attention to the otherness of being. It is to look toward being in stillness and silence. It is to look with a more or less intense desire to know being. To desire to know is to love and it is this desire--love itself--that is the effective condition for realizing this aspiration of thought.

For him--as for the tradition of western reason in which he is consciously standing--this account is not meant as some 'abstract theoretical model' or 'doctrine'. On the contrary, it is meant as a wholly accurate description of all that we know concerning the experience of thinking.

We look at being and our attention is held, still and silent, by the strength and intensity of our desire to know. What may (or may not) happen is a momentary flash of intuition. Eidos, idea, may come into the mind, and with it that understanding appropriate to the being who stands under being.

In the traditional path which his thinking finds and pursues amidst the technological, the human being is the being who loves. Who loves even while subject in the whole--or very nearly the whole--of our being to a necessity that seems wholly--or very nearly wholly--indifferent to our love. We are the creatures who call:

just and beautiful things that are necessary, for we know not how great in reality is the distance that separates the essence of the necessary from that of the good. ${ }^{18}$

In the modem paradigm in which objective knowledge is enfolded towards making, the distance between 'necessity' and the 'good' vanishes. Technology is the turning of necessity in a direction that is, supposedly, toward the human good. Strangely, as we have seen, this assertion of wherein the human good lies--technology--is accompanied by a denial of the meaning of the very term, 'good'.

For western reason at its height--in the philosophy of Plato--the good meant simply that for which a being is 'fitted'. The human being, at our highest, was fitted for the contemplation of and participation in being as beautiful, being as just and, ultimately, being as good. Our standing under being meant that our under-standing of being was radically incomplete. What we could know of good was as nothing compared to the good in the reach of being beyond us, micro- and macro-scopically. For this reason, Plato--and the Greeks generally-did not possess the monolithic certainty characteristic of modernity concerning the best way to stand and live amidst being.

For Grant, as for the Greeks at the apogee of their culture, what is far more real than any specific content that we can give to "good", is our desire for good. Even if being is without goodness, our being is such that it can never be without a desire for good. Consequently, in all times and places, the most elementary task of reason is that of keeping love in check so that we are not led to see being as we want it to be, but to see it as it is. Through the modern notion of 'value', technology becomes the assertion of the human good.

We have seen that when we stand over being as objective, the beauty of 
being vanishes. At the same time, its authentic otherness is lost. The 'object' is being reduced to the level of death or enslavement. In technology, being comes to be 'resource' and an (algebraically) graspable necessity open to our manipulation. In the loss that is implicit to and explicit in the objective stance toward being--the loss of beauty, justice, and good--being stands before us as nothing more than 'raw material' for technology. In this, the otherness of being vanishes before the potentialities of being that our knowing can bring forth.

In Grant's thinking, there are two important consequences to this banishment of beauty and the consequent reduction in the otherness of being as it stands before as object. (1) It allows us to access and accumulate the manifold 'little' truths that are knowable about the objective character of being. This, in turn, empowers us within 'nature'; it gives us a newfound and, of course, a seductive power to act within 'nature'. (2) It creates a vacuum at the core of our being, for we are creatures who cannot help loving; creatures who always and everywhere desire good. It is out of this vacuum at the heart of our being that technology issues forth to assert its own good as beyond question and questioning.

When the butterfly is not present to us as beautiful, it is far easier to kill it with a view to collection, classification, or analysis. When being appears to us beautiful our knowing or understanding of it is not enfolded towards making--or, more accurately, towards re-making; it folds instead towards contemplation and wonder.

In the midst of Grant's thinking about reason, it becomes apparent that the most essential task of education is to teach us to love in a way befitting the kind of being we are. As human beings, we are lovers; and, if we are not lovers of wisdom, we nevertheless remain lovers. If our desire is not detached through orientation towards the best appearance of being--beauty, justice, good--the appearance that reaches beyond being and under which we stand, it will attach itself to that over which it can stand.

Within the tightening circle defined by technology, our desire is directed towards the acquisition of power; towards naked force exercised over other beings including, increasingly other human beings. For Grant, it was, above all, the hideous nature and implications of the modern conceptions of justice that disclosed the darkness of our destiny in technology. Ultimately, the only restraint on our 'passions' or our 'freedom' is the restraint that comes from the perception of being as beautiful and other. What humanity can come to without this restraint lies all about us in the mounting horrors of our century and civilization.

Today, our destiny is to stand over being as the master stands over the slave. In technology, we command (or such, at least, is the illusion and the aspiration). Other beings--'nature'--obeys. Grant frequently reminds us, as well he might, that Plato characterized the tyrant as the worst of human beings on grounds that are as interesting as they are surprising to us:

Human beings are in their essence needing beings, and when othemess has become completely absent for us, we are hardly human beings at all. It must be emphasised that for Plato the opposite of knowledge is not ignorance, but madness, and the nearest that he can come to an example of complete madness is the tyrant, because in that case otherness has disappeared as much as can be imagined. ${ }^{19}$ 
To the master, the tyrant, in so far as he is tyrannical, nothing exists except himself; other beings exist only to serve the interests of his will.

The 'dialectic' of the master/slave relation is deeply inimical to the humanity of our being. As rational beings, we stand in language (and in Plato's view are used by it). At the heart of slavery lies a fundamental disjunction which destroys the very basis of reason in language. The master speaks (to command); the slave listens (to obey). With the condition of slavery, a literal irresponsibility comes to dwell at the heart of language. The responsibility of the human being in language is lost to the extent that enslavement diminishes our freedom to respond within the word. Slavery exalts the few into beings possessed of the power of speech and freed from the need to listen; it diminishes the many to the level of beings who must listen to the word while being deprived of the opportunity, the ability, and power of speech.

In human language, there is no more basic or elemental connection than that which exists between speaking and listening. In so far as slavery produces a disjunction between hearing and speaking, between thinking and the expression of thought, the rational basis of our participation in language is destroyed.

As we have seen, technology for Grant involves a standing of the human in mastery over being. The first and the ultimate dialogue of the human being in language, the di-alogue of the human being and being that we call thinking, appears radically decomposed at the very centre and core of the technological circle. When we stand toward being as object, we stand toward that which has been radically silenced. We also stand toward that which is subject to the commands and manipulations of our own empowerment. The reason that dwells within technology is a reason that speaks to being out of its own empowerment and not responsibly, not with the fundamental character of human language as di-alogue, namely--a waiting upon and listening for a response. The thinking that exists at the heart of technology is a thinking that speaks without listening.

Today, in the West, the people of the Book have become the people in a book. That 'book', written by the story of our own making within 'nature', is a novel entitled "history". It might be better entitled The Collector for within the novel of history, as it is being written by technology, it is doubtful if any of us are any more real than the character of Ferdinand Clegg, "Marquess of Bugs" and it is probable none of us are any saner.

When men come to mastery, one of our first illusions of power is the delusion of mastery over language. We exist in language; it lies at the centre of our being as human and, like all forms of being, the being of the word reaches indefinitely beyond us. To stand under being is, above all, to stand under the word. To be "open to the whole" is, first and foremost, to under-stand the word. It is well to recall that in the ancient tradition of Plato, whose path George Grant's thinking finds and pursues, there is no form of being that towers higher above and beyond us than the being of the word. If we would understand Grant's thinking, it is well to remember that for Plato the ideas are not 'solidified abstractions' but the attributes of Being Itself which is God. ${ }^{20}$

We do not, in this view, use language, reason, or philosophy; they (it) use(s) us. In Grant's account, the reason which belongs to western philosophy is that which consciously consents to our being used by the logos. In this sense, to think is to enter into di-alogue with being and ultimately, through being, with Being. Thus, in the first place we must listen before we speak. The most primal 
and primary form of our thinking is waiting, in stillness and silence, for the revelation of the word. On all levels, the origins of our coming into language lie in listening.

Modern philosophy, as it exists within the tightening circle of technology, is often defined as an attempt to use language with all the hardness and rigour of mastery (as opposed to being used with such). For example, the contemporary 'philosophy of education' sometimes attempts to give content to the meaning of the word by defining for us the (logically) 'necessary and sufficient' conditions of its usage.

We must conclude by reaffirming that for Grant there is no such thing as a 'philosophy of education'. On one level, the phrase would appear to him in the guise of a non-sensical tautology. Literally, the love of wisdom of education. What can that mean?

If we examine the various meanings that the word has in his writings, at least in the later writings that are the basis of this essay into his thinking, we find that the word 'education' often has the basic significance of its root or primal meaning. It is the social process by which we come, for good or ill, to inherit the assumptions, the ways, the accumulated opinions and truths of our ancestors. It is this meaning that is expressed in his critique of the educational process within technology and its civilization.

When he speaks of the best education, the one that most befits us as beings who are called to under-stand being, the term is closely identified with 'philosophy', that form of reason which dwells in language in "openness to the whole". Hence, we might hazard to say that for him the best educated are the most philosophic; the openness to the whole that is being. In terms of our own civilization, the best educated are also, more or less clearly in his view, those who most dwell within the account of reason given in Greek philosophy at its height. To formally understand technology, the thinking of the Greeks must be alive to us because the seeds, the origins, of the enterprise--be they seeds of greatness or decay--lie within their thinking.

By this point, it almost goes without saying that for Grant the process of education as it exists within our technological society is a process that largely serves to darken and obscure the possibility of the best education and the stance of philosophy into which it leads. The modern educational process is largely organized precisely to keep us from coming into reason through education. The entire weight of the civilization that belongs to technology is directed against the best education because the rebirth of philosophy directly threatens the uninhibited continuance of the technological enterprise itself.

At this point, we ought not to find this fact very surprising. Indeed it would be surprising if it were not so. In any society, education--as an organized social process--serves as the primary mechanism of transmitting and continuing that society's way and destiny as a civilization. Our particular destiny is that of technology and, as we have now seen in the course of Grant's analysis, that destiny stands intensely and supremely against the destiny of western reason at its height amongst the Greeks.

Perhaps this opposition in Grant's writings between education within the paradigm of technology and philosophy understood traditionally is nowhere more evident than in his substitution of the term "multiversity" for the old term 'university'. In technology, we stand over a multiversity of beings which are 
summoned forth as 'objects' for study within our educational institutions. In the multiplicity of objects studied, there is no unity. The unity of what is studied lies in the unity of the method that is termed 'scientific objectivity'. In the older institution of the university, the situation was reversed. The unity lay in the multiversity of beings under study. It lay in the univocal character of being itself.

The curriculum or content of contemporary education as a social process is, Grant concludes, infused with and--increasingly--organized around the project of objective reason in its modern scientific form. As we have seen, by standing over being in the way of objectivity, a great deal can be learned about 'objects' and the 'objective' textures of 'nature' around and in us. What cannot be known through such a stance, however, is anything that is greater than either the 'objective' beings under study or than the 'objective' or object-like knower standing over them. The greatness of being as known and as knower is excluded from the focus of attention in the objective way of standing toward being. This stance deliberately and consciously functions to exclude from the attention of the mind the entire significance of being as it reaches above and beyond us.

It is this for Grant, above all else, that accounts for the dying within the modern multiversity of the 'humanities' or 'arts' as a living portion of our culture. In the height of its mounting prestige the scientific method of objective knowing has been gradually extended to, and been appropriated by, what were popularly supposed to be the non-'scientific' studies within the old university curriculum.

Thus, under the new 'research' oriented scholarship of someone like Canada's illustrious Northrop Frye, the study of literature ceases to be the study of texts capable of teaching us something beyond ourselves. It becomes, instead, a way of classifying and analyzing those texts as 'objects'.

Hence, in our objective stance as moderns we bring to the Bible, to the plays of Shakespeare and Aeschylus, or to the Dialogues of Plato, an overstanding that renders such texts essentially silent. In the presumed superiority of our knowing as modern objective knowers, we tower over such texts. The very stance with which we stand toward them--objectivity--excludes us from the possibility of being carried beyond ourselves by whatever understanding of being they have to offer.

The very procedure of research means that the past is represented as an object. But anything in so far as it is an object only has the meaning of an object for us. That is why it is quite accurate to use the metaphor of the mausoleum about our humanities research. Moreover, when we represent something to ourselves as object we stand above it as subject--the transcending summoners. We, therefore, guarantee that the meaning of what is discovered in such research is under us, and therefore in a very real way dead for us in the sense that its meaning cannot teach us anything greater than ourselves. ${ }^{21}$

Consequently, for Grant, in any "sane system of education"-.-"and I am not implying that the North American system is that "--scholarship is an activity that exists as a means toward the journey of philosophy into "openness to the whole".

In this regard, he sees a radical difference between the scholarship of the past and the research oriented scholarship within the present day multiversity. 
Previously, scholarship waited upon the past in the hope of discovering truths that "might help us to think and live in the present". Currently, scholarship sees no reason to wait upon the texts of our past. It is us and not our ancestors who are in possession of the truth in its highest and greatest form. Instead of waiting upon such texts in the spirit of under-standing, our scholars rush actively toward them as over-standers, eager to demonstrate, confirm and show off the superiority of their knowing over that of the 'ancients' and the 'primitives'.

At the heart of technology lies the aspiration of thought towards mastery. However, in scholarship, as in anything else, the master is not likely to learn much from the slave, for the simple (but very good) reason that before him the slave is called to be silent. Today,

research scholarship in humanities cannot thus wait upon the past, because it represents the past to itself from the position of its own command. From that position of command you can learn about the past; you cannot learn from the past. This stance of command necessary to research therefore kills the past as teacher. 22

Within the ever tightening circle defined by our technology, our society's educational institutions are enfolded toward the maintenance and cultivation of this silence. Through the role played by modern scientific objectivity within them, they have become institutions central to the progress of technology and the civilization to which it has given rise.

For Grant, Heidegger's conclusion--that we are beings toward death--is the height to which thinking has come within the tightening circle of technology. This terrible truth of our condition within technology's circle is for him clearly evident in the dying of the past within our multiversities.

Within the circle, we are no longer beings toward good, as Plato claimed, because we have become beings toward technology as 'the good'. The good of technology is the mastery of being and to master something (or someone) is to exert a killing power and control over them. The good of technology lies in its own triumph over all that is. As a part of what is, the relics of the past must be either silenced or obliterated. Other still living civilizations must be brought before our own and reduced to the quiet level of 'objectivity'. The whole of being as we encounter it must be brought to stand before us, an 'object' under our control and as a 'resource' for whatever we wish to make out of it. With Plato, Grant says that we are either beings toward good or beings who dwell in madness. 


\section{Notes}

${ }^{1}$ George Grant, "Tyranny and Wisdom," in Technology and Empire: Perspectives on North America (Toronto: House of Anansi, 1969), 82.

"See also his essay, "Thinking about Technology," in Technology and Justice (Toronto: House of Anansi, 1986), 34.

3"'The University Curriculum," Technology and Empire, 131.

4"Faith and the Multiversity," Technology and Justice, 36. See also, "Research in the Humanities," 98-99 and "Thinking about Technology," 21.

5"Faith and the Multiversity," 36.

${ }^{6}$ What is significant often stands forth in the extreme.

${ }^{7}$ The Collector (London: Pan Books, 1969), 80.

${ }^{8}$ Technology and Empire, 133. See also his Technology and Justice, 76-77.

${ }^{9}$ Technology and Justice, 34.

10 Ibid., 22.

${ }^{11}$ Martin Heidegger, An Introduction to Metaphysics, translated by Ralph Manheim (New Haven: Yale University Press, 1959), 15.

${ }^{12}$ Technology and Justice, 33.

${ }^{13}$ Technology and Empire, 119.

14 Ibid., 129.

${ }^{15}$ Technology and Justice, 17-18.

16Ibid., 38. Translated by Grant himself from Simone Weil's La Pesanteur et la grace (Paris: Plon, 1948).

${ }^{17}$ Ibid., 38.

${ }^{18}$ Plato, The Republic, Bk. VI, 493c.

${ }^{19}$ Technology and Justice, 73-4.

${ }^{20}$ It ought to be noted here that for Grant a profound consonance existed between Christianity and the philosophical tradition of Plato and Socrates. Due to the obvious limitations of space here, I have set this vital connection and aspect of his thinking aside.

${ }^{21}$ Ibid.

22Ibid., 99-100. 